Forthcoming in The Review of Politics

Provisionally Scheduled for Volume 81, Issue 1, Winter 2019

\title{
The Ethics of Interpretation in Political Theory and Intellectual History
}

Michael L. Frazer

Lecturer in Political and Social Theory, University of East Anglia

michael.leo.frazer@gmail.com

\begin{abstract}
$\underline{\text { Abstract }}$
Scholars studying classic political texts face an important decision: Should these texts be read as artifacts of history or as sources for still-valid insights about politics today? Competing historical and "presentist" approaches to political thought do not have a methodological dispute - that is, a disagreement about the most effective scholarly means to an agreed-upon end. They instead have an ethical dispute about the respective value of competing activities that aim at different purposes. This article examines six ethical arguments, drawn primarily from the work of Quentin Skinner, in favor of the historical approach. It concludes that while both intellectual history and presentist theory are ethically justifiable, the best justification of the former enterprise is that it can help us achieve the purposes of the latter.
\end{abstract}

\section{Acknowledgements}

I would like to thank all those who provided feedback on this piece, including those who attended presentations at Oxford, Princeton, Cornell, the National University of Singapore, and Texas A\&M, as well as the editors and reviewers who have gone above and beyond the requirements of their professional duties. 


\section{$\underline{\text { Introduction }}$}

Ethics, under a roughly Habermasian view, is a realm of discourse in which any of us may be called to offer justifications of our activity in terms of values that we expect our interlocutors to share. Sometimes, it is reasonable to refuse a discursive demand for justification. In other contexts, however, evading another's demand for justification would itself be unjustified; whether this is the case is itself a matter of further ethical debate.

We often do not want to evade others' justificatory demands. To the contrary, our wellbeing depends on the fact that much of what we do is intersubjectively justifiable. As Susan Wolf has argued, in order for a putatively valuable activity to contribute to a meaningful life, "not only must the locus or recipient of value lie partly outside of oneself, the standard of judgment for determining value must be partly independent, too."1 John Rawls concurs, arguing that "unless our endeavors are appreciated by our associates it is impossible for us to maintain the conviction that they are worthwhile." 2 Rawls later came to see that, while the need for this kind of ethical recognition applies across much of our life, it is particularly important when it comes to our work. ${ }^{3}$ The very idea of employment in a vocation implies pursuing a purpose that can be justified as valuable; finding this kind of meaningful work is a central component of human flourishing. ${ }^{4}$

The scholarly vocation is no different from any other in this regard. While many have quipped that academic infighting is so intense because the stakes are so low, the stakes are actually quite high for those whose reputation as valuable professionals is in question. What is more, ethical arguments in the academy often interact with non-academic life in important ways. Such is certainly the case with the disagreement that I will be analyzing here, which is about how we ought to study ideas and texts that remain central to popular ethical and political discourse. 
Scholarship on these matters is no different from any other kind of activity in being liable to a demand for justification; it does not automatically follow that since all human activity is liable to the justificatory demand, the academic study of this demand is itself of any ethical importance. When it comes to justifying their work, ethicists and political theorists have the same discursive responsibilities as anyone else.

The debate at hand involves three possible approaches to the study of discursive justification in the political sphere, practiced by scholars who I am calling historians, ahistorians and transhistorians or presentists. The first two parties in this dispute believe that the study of political discourse should be bifurcated between them, with what they call "the history of political thought" sharply distinguished from what they consider to be "political philosophy." The former of these enterprises, though practiced in both history and political science departments, is fundamentally a branch of history. Its proper goal is to understand political texts as historical artifacts from a particular time and place. The latter enterprise - to be practiced in philosophy and philosophically-oriented political science departments - is to be treated as an essentially ahistorical undertaking.

A third group of scholars defies this bifurcation. Jeffrey Green has called these authors "pupils" of the political classics; ${ }^{5}$ Deborah Baumgold has labeled their work "political commentary." Their critics, most notably Quentin Skinner, often call them "presentists." Leading practitioners of a presentist approach in the second half of the twentieth century included Hannah Arendt, Isaiah Berlin, Michael Oakeshott, Leo Strauss, Hans-Georg Gadamer, Sheldon Wolin, and Judith Shklar. Each of these authors has students carrying on their work today. 
Divided among themselves on almost all matters both substantive and methodological, most presentists would understandably object to being lumped together as I am lumping them here. Despite all their differences, however, they share two common opponents. ${ }^{7}$ Against ahistorical philosophers, they argue for the continued importance of reading old books. Against historians, they argue that these books should be interpreted as making contributions to ongoing political debates.

To be sure, each figure in this triad - the historian, the ahistorian, and the transhistorian or presentist—is a Weberian ideal type, and much interesting scholarship on political thought (notably cross-cultural, comparative political theory) is difficult to classify under this typology. As with any system of ideal types, however, the gain in clarity here is worth the price in taxonomic subtlety. While Weberian idealizations are useful in descriptive sociology, they are even more useful in normative ethics, a field in which the goal is to clarify positions in an abstract debate rather than to capture all the messiness of actually-existing discursive practices.

This essay will focus on the debate between presentists and historians. Since historians and ahistorians are often allied, objections to presentism grounded in the ahistorical approach will also be discussed when relevant. A full consideration of the arguments in ahistoricism's favor will nonetheless have to wait for a future occasion. Let us assume, then, that a scholar has decided to continue reading old books about politics. How is she to choose between writing a work of intellectual history and writing a work of presentist theory?

This is not a matter of methodology, an instrumental matter of selecting the proper technique to be used for solving a given intellectual puzzle. It is a matter of what sort of questions we should devote our careers to trying to answer in the first place. A whole host of choices about the respective value of addressing these competing types of questions must be 
made: collective choices in graduate and undergraduate curricula, in academic publishing, and in faculty hiring, as well as individual choices about what each of us reads and writes.

These choices are all unavoidably ethical. They ask for an interpersonally acceptable justification of how we choose to balance competing values. Some of the values to be weighed may be moral in a narrow sense: they may involve questions of interpersonal obligation, of "what we owe to each other." All, however, will be broadly ethical, including the full range of human values alongside narrowly moral ones. While much of the ethical discussion that follows will be about interpersonal responsibilities, other values — such as the intrinsic value of truth and the values internal to certain professions_-will play a role as well.

It is important to distinguish this ethical debate between historians and political theorists about the value of their respective vocations from the methodological debates that both historians and theorists have among themselves. Mine is not yet another methodological argument against Skinner or the so-called "Cambridge School," but is a continuation of a now-neglected argument that predates the emergence of Skinner's preferred methods. Skinner is famous for his methodological criticisms of earlier historians of political thought such as George Sabine. Before Skinner's methodological criticism, however, David Easton subjected Sabine and his ilk to a very different, explicitly ethical line of criticism to which Skinner himself may also be liable. Easton argued that scholars of political thought have failed to live up to their ethical responsibilities, regardless of their methods, if "they do not use the history of values as a device to stimulate their own thoughts on a possible creative redefinition of political goals."8

Although my argument is not against Skinner's methods, it nonetheless remains the case that Skinner's allegedly methodological writings contain some of the strongest ethical arguments available for a "properly historical" approach to political thought. ${ }^{9}$ Throughout the vast literature 
that has developed around Skinner's writings over the last half-century, however, there has heretofore been little attempt to evaluate his ethical arguments as such. Some commentators have even gone so far as to insist that we misread these essays if we see their concerns as anything other than "narrowly methodological."10

In fact, Skinner's concerns have always been unambiguously ethical. In his seminal essay "Meaning and Understanding in the History of Ideas," Skinner explicitly argues that that "to demand from the history of thought a solution to our own immediate problems is... to commit not merely a methodological fallacy, but something like a moral error." ${ }^{11}$ It is morally incumbent upon us, in his view, to overcome the narcissism of the present moment - a narcissism equally present in both the parochialism of ignorant ahistorians and in the naïve presentist demand that the past directly serve present political purposes. Only when we see the past for what it truly was can we begin to overcome the constraints that the present places on our imaginations; accurate history is therefore a necessary propaedeutic for effective socio-political criticism, while presentism only gets in the way of both.

In addition to this key argument for the critical importance of history (with "critical" taken here in both senses of the word), this essay will also examine five other distinct ethical arguments that Skinner discusses when justifying the intellectual-historical vocation: four more arguments he has endorsed to varying degrees at some point in his long and varied career, as well as one he has discussed at some length but consistently rejected. Rather than seeking to identify what Skinner intended to do with these ideas at any particular historical moment, my aim is to collect the best ethical arguments for reading political thought through the lens of intellectual history. When others have more fully explicated arguments that Skinner has suggested, I will therefore draw on their versions of these arguments as well. ${ }^{12}$ My catalogue of arguments on the 
matter might not be exhaustive; the question remains open as to whether historians of political thought may have others available in defense of their chosen vocation. These are, however, the six ethical arguments most prominent in the work of one of this vocation's most prominent defenders, who is also one of presentism's most prominent critics.

It is therefore noteworthy that, while each of these arguments is compelling, none can successfully establish that intellectual history is ethically justifiable while presentist theory is not. That said, however, I will not be defending the equally over-strong thesis that only presentism is ethically acceptable. My claim is that the rejection of both of these exclusivist theses does not imply a tolerant pluralism of autonomous, mutually indifferent academic enterprises each of which is justified independently of the others. To the contrary, while both intellectual history and presentist theory are justified, the single most persuasive argument in Skinner's work for the value of the former enterprise is that it can help us achieve the purposes of the latter.

\section{The Argument from Impossibility}

Although Skinner's “methodological” essays regularly invoke ethical values to justify the practice of intellectual history, the bulk of his arguments are not explicitly ethical. At times, Skinner seems to deny that the choice between intellectual history and presentist theory is really a choice at all. Drawing on epistemology and the philosophies of science and language, Skinner sometimes argues for the impossibility of any but his own interpretive approach. The original version of "Meaning and Understanding" claims that its philosophical arguments "establish and prove the case" for his methodology, "not as a suggestion, an aesthetic preference, or a piece of academic imperialism, but as a matter of conceptual propriety, a matter of seeing what the 
necessary conditions are for the understanding of utterances."13 There is simply no understanding of texts, in this view, outside of their history. Here, methodological and ethical questions collapse into each other. If one simply cannot understand a book except through its history, one ought not to waste time in a vain attempt to do so.

There are similar arguments to be heard from some presentists. Gadamer, for example, insists that the kind of history that Skinner would later demand "is a futile undertaking in view of the historicity of our being," since any interpretation we can give "is always co-determined... by the historical situation of the interpreter." 14

I will not attempt to refute all the arguments put forward by Skinner, Gadamer and their respective followers for the impossibility of any but their preferred interpretive approach. This work has already been done by others, demonstrating precisely why it is possible to understand old books both as historical artifacts and in ways that help illuminate pressing issues today. ${ }^{15}$ This literature confirms that E. D. Hirsch was correct to argue that the "meaning" of a text (as determined by authorial intention) can be separated from its "significance" (as determined by reader responses).${ }^{16}$ Both uncovering its original meaning and its later significance are legitimate ways of reading a text, and interpreters are free to focus on a text's significance for any of its readers over time, including ourselves. Intellectual historians widely accept Rezeptionsgeschichte as a distinct form of legitimate intellectual activity, and presentism is merely a kind of Rezeptionsgeschichte in the first-person. Perhaps for this reason, Skinner has moved away from the strongly exclusivist position of his early polemics. In the revised version of "Meaning and Understanding," Skinner's argument can no longer "establish and prove" the inescapability of his approach, but only "goes some way towards establishing a case for this methodology."17 
A concrete example of the multiple possibilities available when interpreting an old political text may be illuminating. By 1988, Skinner was willing to admit that it is philosophically coherent to ask presentist questions such as whether Machiavelli was correct to believe that mercenaries always threaten political liberty. Yet he still maintains that such a question is "likely to strike a historian as strange." Asking whether Machiavelli is right about mercenaries is "somewhat analogous to asking whether the king of France is bald. The best answer seems to be that the question does not really arise." 18 It is certainly true that, for a scholar seeking only to situate Machiavelli's writings as historical artifacts, questions of this sort are beside the point. Yet they may arise for others reading Machiavelli for other reasons.

In 1989, the first major private military company of our time, Executive Outcomes, was founded in South Africa. It soon came to play a central role in conflicts across the developing world. Yet despite the rapid rise of private armies over the past few decades, Skinner left his discussion of the matter unchanged in the 2002 version of his essay. ${ }^{19}$ While France may no longer have a king, bald or otherwise, mercenaries are now with us once more. It is certainly possible to ask whether they pose the threat to liberty that Machiavelli insists that they always do.

An ahistorian would advocate trying to answer this question without any reference to Machiavelli's texts themselves. Aside from the rather pedantic objection that this would involve a failure to properly cite one's sources, it would also involve abandoning a resource with the potential to enrich our answer to the question at hand. To be sure, it may not be as easy to draw on Machiavelli as it would be to draw on a more recent source about private military companies. There are both similarities and differences between the mercenary armies fighting the wars of renaissance Italy and the PMCs fighting the global conflicts of the twenty-first century. ${ }^{20}$ To 
make use of Machiavelli today, a scholar must trace both analogies and disanalogies with care. Whether the result will prove more valuable than an evaluation of the mercenary issue drawing only on material written in the past three decades cannot be known until after the work is completed. What is important for our purposes, however, is that the real issue is one, not of the possibility, but of the value of these competing approaches.

For those wishing to hold on to the idea of a single true understanding of a given text, an ethical turn offers the possibility of a return to a revised form of hermeneutic exclusivism. Ronald Dworkin, for one, puts forward a "value-based general theory" of interpretation. His thesis is that the best interpretation of a given object is the one that best advances the values promoted by the interpretive practice in question. Debates about the interpretation of a text are, in Dworkin's view, implicit debates about the point of interpreting it. ${ }^{21}$ Hirsch agrees; since he believes that there is a choice between focusing on a text's original meaning and its later significance, Hirsch argues that, like any choice, this decision "belongs to the domain of ethics rather than the domain of ontology." ${ }^{22}$ In his untimely meditation on the subject, Friedrich Nietzsche also offers a value-based assessment of history in several of its diverse forms. Of course, Nietzsche's values are quite different from Dworkin's or Hirsch's; the question here is to what degree each type of history advances or undermines the non-moral value of "life." ${ }^{23}$ Yet although Dworkin, Hirsch, and Nietzsche may disagree on most substantive ethical question, they all agree that hermeneutic questions are fundamentally ethical. If they are correct, then the best interpretation of a text is the one that maximizes its value. 


\section{The Argument from Responsibilities to the Dead}

When a text has the potential to shape today's public discourse for the better, the value of pointing out its current significance is obvious. Questions about the dangers of mercenaries are urgent for all those whose liberty and security are at stake. If our ethical responsibilities to help the living answer these questions lead us to disregard the historically-verifiable intentions of long-dead authors, so be it.

A historian might respond by arguing that our ethical obligations to the dead are actually quite considerable, and may even trump our responsibilities to the living. To draw on old books for present political purposes, and hence to read them in ways that their authors never intended, is to recruit the deceased into political causes without their consent. This is the basis of Hirsch's main argument for the ethical priority of the original, intended meaning of a text over its current significance. To “simply use an author's words for our own purposes without respecting his intention," Hirsch insists, is to "use another person merely for our own ends," a clear violation of Kant's categorical imperative. ${ }^{24}$

Certain passages from Skinner suggest an ethical argument along roughly these same lines. Presentist theory, Skinner claims, has a "sinister undertone" as "a means to fix one's own prejudices onto the most charismatic names under the guise of innocuous historical

speculation." 25 Much of the concern here is with the way that citing the glorious dead can play a misleading role in political rhetoric; Skinner warns us against being awed by the invocation of important-sounding names. There is no denying that presentists need to evaluate old arguments carefully, evaluating them on their merits and avoiding fallacious appeals to authority. Yet Skinner's concern is not only with unjustified appeals to authority in today's political discourse; he also cares about past authors for their own sake, lauding intellectual history as the only means 
of properly understanding and respecting their intentions. Contra Voltaire, he insists that it is not real history, but only presentist theory, that is "a pack of tricks we play on the dead." 26

Whether we can truly owe obligations to the dead - whether the dead can be harmed or wronged - is the subject of a lively philosophical literature. ${ }^{27}$ Yet it is not necessary to settle any metaphysical questions about the ethical survival of the biologically deceased for our purposes here. Even philosophers who argue that we do have genuine moral obligations to the dead—not to defile either their corpses or their posthumous reputations, for example — nonetheless admit that "the interests of the dead are often justifiably overridden by the interests of the living." 28 If the best way to save the liberty of the living is in some sense to play a "pack of tricks" on Machiavelli, violating a pro tanto prohibition on such trickery may be justified, all things considered.

At the same time, however, even those philosophers who argue that we do not have genuine obligations to the dead argue that our treatment of the dead can be an indirect way of fulfilling important obligations to the living. For example, we can soothe the anxieties of those who worry about what will happen to their bodies after they die by establishing a social practice of respecting the wishes of the dead regarding these matters. ${ }^{29}$ This is why an insistence on explicit consent to postmortem organ donation may be important even if Epicurus were entirely correct to insist that nothing can harm the dead.

Fortunately, presentist theory is more akin to voluntary organ donation than it is to grave robbery. Most of the writers whom a political theorist might want to recruit for present use gave explicit consent to the procedure while they were alive. Nietzsche was hardly alone in writing self-described preludes to the philosophy of the future, and Thucydides was not the only author to intend his work not as "a piece of writing designed to meet the taste of an immediate public," 
but as something "to last forever." ${ }^{30}$ Even in cases where such explicit statements cannot be found, an implicit intention to speak to the future can be found in most classic works of political thought, often by virtue of their assertion of universal claims about political phenomena which are not limited to the conditions of their own time and place, or simply by virtue of publishing their thoughts in a medium capable of long-term preservation and available to an open readership. ${ }^{31}$

Skinner acknowledges that post-mortem effects may very well be among an author's historically-verifiable intentions. Writers, he grants, may seek to communicate not to "an immediate audience or society, but to appeal over its head to some indeterminate future audience, perhaps to posterity itself." ${ }^{32}$ Presentists show a morally proper form of respect to dead authors when they respect their intention to have effects on the future that they could not foresee. Often, their most important intention was to create a work that would take on new significance in different contexts over time, even if they could never predict the precise details of how this general intention would be carried out by future generations. They hope to be like the scientist imagined by Dorothy Grover, whose cancer drug turns out to cure AIDS, but who died before the new disease was discovered; the value of his work is "enhanced by completely unanticipated achievements." ${ }^{33}$

To return to our previous example, Machiavelli explicitly states that his intention is "to write something useful to whoever understands it," with no implied limitations as to time or place. ${ }^{34}$ It is hard to imagine that the author of the famous 1513 letter to Francesco Vettori, where he describes so proudly how he enters into the conversations of the ancients,${ }^{35}$ would object to entering our current debate about the dangers of PMCs, even if he could never foresee the details of privatized warfare in the age of Blackwater. 


\section{The Vocational Argument}

Historians might concede that contemporary applications of Machiavelli's ideas could perform an important service to the living without violating any obligations to the dead. Even if it is ethically incumbent upon someone to perform this service, however, historians can nonetheless reply that it is not their responsibility, since it is not historical work. Skinner makes clear that he does not believe that we are "precluded" from asking whether Machiavelli is right about mercenaries. He is "merely insisting" that this is not "our task as historians."

For certain individuals engaged in certain vocations, it may be unethical to play the ethicist. My station and its duties may justifiably demand that I refrain from active normative evaluation. The most famous statement of academic professional ethics, Weber's "Science as a Vocation," argues that it is the responsibility of all scholars to remain value-neutral in roughly this way. ${ }^{37}$ Even if this is not true of all scholars — even if ethics and political theory are legitimate academic activities, not something to be left to politicians and preachers-surely it is true of scholars who call themselves historians.

As John Dunn observes, most arguments in the history profession are attempts "to legislate for the type of historical explanations which should ideally be given, a lengthy exercise in the persuasive definition of the adjective 'historical." ${ }^{138}$ Skinner recognizes all such rhetorical strategies by "innovative ideologists" wielding "evaluative terms" to be attempts to "impose a

particular moral vision on the workings of the social world." ${ }^{39}$ The attempt to embrace "history" as a rallying point is understandable in this case, especially given the struggles that intellectual historians have faced in establishing the legitimacy of their enterprise in departments dominated by social and cultural historians hostile to their work. 
Yet Skinner himself recognizes that a viable alternative to claiming a key evaluative term as one's own is to instead challenge the normative valence of a term itself. ${ }^{40}$ Presentists could probably never win a debate with intellectual historians over which is practicing "real history." 41 It is important to realize, however, that "historical" can easily function as a value-neutral descriptor, or even as a term of opprobrium, as it does in many analytically-oriented AngloAmerican philosophy departments. Although historians might not wish to consider this possibility, it is entirely possible that work which least qualifies as history is what is most valuable, and what best qualifies as history is what is least valuable. If gaining practical wisdom from great books is fundamentally unhistorical, perhaps the proper response is to conclude, "Well, so much the worse for history."

As Arthur Applebaum argues, what creates an ethical justification for abiding by the duties of a particular profession is the importance of that profession for one's larger society. ${ }^{43}$ If a particular vocation has no significant value - moral, instrumental, aesthetic, or otherwise - then the internal rules of that profession are not a legitimate branch of any larger human ethical system. If Machiavelli is right about the valuelessness of mercenary armies—not merely their threat to liberty, but also their unreliability and their lack of any admirable military virtues - then the world might be better without anyone pursuing the vocation of a mercenary. The question is therefore whether choosing to devote one's life to either intellectual history or presentist theory is justifiable in a way that devoting one's life to the profession of a mercenary may not be. Each of the three remaining arguments examined will address this question. 


\section{The Argument from Intrinsic Value}

Although this essay has so far only discussed arguments for the value of intellectual history that Skinner endorsed at some point in his career, it is also worth including one argument that he discusses at length, but consistently rejects. This line of argument was popular among historians a generation older than Skinner. Herbert Butterfield, for example, argues that, whatever our purposes in taking up the historical calling, "we cannot save ourselves from tumbling headlong into it and being immersed in it for its own sake." 44 It might be argued that because history has intrinsic value - because it is a vocation to be pursued for its own sake, without reference to any moral or non-moral value external to the practice of the profession itself-historians do not have to make any further ethical argument in its defense.

G. E. Moore insisted that, in support of claims of intrinsic value, "no relevant evidence whatever can be adduced." ${ }^{45}$ We usually explain why something is valuable in terms of its extrinsic connections to other valuable things. Since this sort of explanation cannot work in cases of intrinsic value, it might be thought that no explanation of intrinsic value is possible, and all we are left with is the appeal to intuitive self-evidence. In fact, however, there is a great deal one can say in defense of the claim that some entity has intrinsic value. Robert Audi has argued that nothing in the nature of claims about intrinsic values entails "the indefeasibility of our justification for believing them... Theorizing, or even careful but ordinary reflection, may defeat that justification." ${ }^{\prime 6}$ Historians may intuitively feel that their vocation is intrinsically valuable, but unless something more can be said in defense of this view, it is quite possible that this intuition will be overturned upon reflection.

Since history itself is not among the classic lists of intrinsic goods, its practitioners could certainly begin by explaining how their form of scholarship is one species within some larger, 
intrinsically good genus. Pleasure is one candidate, and knowledge is another. Each has been defended as an end in itself, the former most famously by Epicureans and Utilitarians, and the latter by non-utilitarian defenders of the liberal arts from Aristotle to John Henry Newman. ${ }^{47}$ Perhaps suspecting that more and greater pleasures could be found in other activities, historians such as G. R. Elton have typically defended their profession in terms of the intrinsic value of historical knowledge. ${ }^{48}$

An appeal to the intrinsic value of historical knowledge, however, cannot give us an ethical basis for our vocational choice, all things considered. The world is filled with intrinsically and extrinsically valuable entities. It might be the case that something genuinely has intrinsic value, but only to a vanishingly small degree, such that any reason to pursue this value is always overridden by the need to pursue other (intrinsic or extrinsic) values. ${ }^{49}$ As a result, the knowledge that something has intrinsic value of some sort gives us only a weak, pro tanto reason for pursuing it. Knowledge of historical truth may indeed be intrinsically valuable, but the world is filled with truths we might come to know, both historical and otherwise, and the intrinsic value of knowledge itself gives us no reason to privilege historical knowledge over any other kind.

Skinner recognizes the overwhelming surplus of potential truths that we could pursue. This insight is the basis of Skinner's devastating critique of Elton's defense of history as the pursuit of intrinsically valuable knowledge. Skinner imagines himself a befuddled graduate student of Elton's who has chosen to study Chatsworth House in Derbyshire. "But how can one hope to set about seeking the truth, simpliciter, about such a thing as a house?" Skinner asks. "Will it not be necessary to approach the study of the house with some sense of why I am studying it, why it might be of interest, before I can tell how best to go about examining it?" Yet if our goal is only knowledge for its own sake, "Does this mean that all the facts I might discover 
about Chatworth are of equal interest? Am I just to go there and start making a list of anything it occurs to me to say about it? If this is all I am expected to do, might I just as well be studying something else, perhaps anything else?"50

Even if we decide that it is our calling to seek historical knowledge for its own sake, there is so much historical knowledge to be had about even a single house that, without some extrinsic standard of choice, we will be paralyzed. This is not to mention all the historical knowledge that could be had about the rest of the human past, and the vast amounts of knowledge that other disciplines (presentist theory among them) could provide about other aspects of the universe. "We can't do it all," Beverly Southgate concludes, and so we "must choose, and for some reason." 51

Our choice becomes even more complicated when we realize there is probably not only one type of intrinsic good in the world, but several. We must not only learn to weigh pleasure against pleasure, or knowledge against knowledge, but knowledge against pleasure, and both against other values, most notably social and political justice. Although this is hardly the place to craft a comprehensive hierarchy of intrinsic values (if such a hierarchy of seemingly incommensurable goods is even possible), ${ }^{52}$ there is a widely held belief that it is not knowledge and pleasure but justice and virtue which should rank near the top. No amount of knowledge, Cicero argues in De Officiis, can trump political justice:

For there is no one, surely, however greedy he is to examine and understand the nature of things, who, though contemplating in his studies the highest objects of learning, would not cast them all aside, if his country were suddenly and critically endangered and he could come to its aid or relief... From all this we realize that the duties of justice must be given precedence over the pursuit of knowledge and the duties imposed by that. For the 
former look to the benefit of mankind, and a man should hold nothing more sacred than that. $^{53}$

We might explain Cicero's intuitions by arguing that the intrinsic value of knowledge is overridden by the greater intrinsic value of justice. Alternately, we could argue that the intrinsic value of knowledge is conditional on its compatibility with justice, just as Kant argues the goodness of all other goods is conditional on their accompanying a good will. Either way, it is unclear whether scholars could ever be justified in remaining in their studies while their polities falter around them — perhaps because of unjust, expensive, and unwinnable wars provoked by self-interested mercenaries — unless their scholarship can be understood as itself providing a needed service to their fellow citizens. ${ }^{54}$ Presentist theorists typically intend their work as a direct contribution to the pursuit of justice in their societies. ${ }^{55}$ Intellectual historians, if they wish to point to a similar contribution, must point to some more indirect benefit.

\section{The Argument for Critical History}

Given that he rejects any argument grounded in the instrinsic value of historical knowledge, Skinner has always maintained that, far from evading their social responsibilities, intellectual historians perform an all-important service to advance the progressive realization of justice in their societies. At times, Skinner has also argued that presentist theorists cannot contribute anything of comparable value to the cause of justice and are more likely to harm than to benefit their society.

Throughout his career, Skinner has emphasized the power of genuine history to check our tendency to "fall under the spell of our own intellectual heritage." Such history can "help to liberate us from the grip of any one hegemonal account of those values and how they should be 
interpreted and understood. ${ }^{56}$ Although many have discussed this use of history under the Nietzschean sobriquet of "genealogy," it can also be understood as what Nietzsche calls "critical history. ${ }^{" 57}$ Skinner argues that intellectual history serves its critical function by revealing "not the essential sameness, but rather the essential variety of moral assumptions and political commitments" defended by classic texts. This is the source of the canon's real "moral value." 58

Recognizing the difference between our normative commitments and those of the past frees us to re-evaluate what we once believed — not because we might adopt past values once again, which Skinner here insists we would not, but because the very absurdity of doing so reveals the historical contingency of all human values. Presentists searching for useful parallels between past and present only serve to mask this contingency, and thus only serve to bind us more strongly to the imagined traditions which we falsely assume to support our current prejudices.

Under this critical view, when intellectual history intersects with our current concerns, it does so in a negative way—debunking the pseudo-historical myths that authoritative traditions tell to legitimate their authority. Presentist theory searches for authorities; intellectual history, by contrast, stands opposed to all authorities, criticizing everything and defending nothing except autonomy itself. Yet precisely insofar as they cannot guide our choices, critical historians can claim credit for setting us free.

After the criticism of tradition is complete, the past can no longer offer the practical wisdom that we once depended on to guide our existence. Nietzsche understood that critical history, which "cruelly tramples over every kind of piety," is "always a dangerous process, especially so for life." ${ }^{59}$ The strong may be able to handle the new-found freedom bequeathed to them by critical historians, but the rest will descend into deadly nihilism. Now, as Skinner 
famously puts it, we must "learn to do our own thinking for ourselves" up to the task. Most of us simply cannot survive without some form of practical guidance from others.

There is nothing inherently base or servile about turning to others for advice in times of need. No less a defender of the freedom of individual thought than J. S. Mill insists that "even the originality which can, and the courage which dares, think for itself, is not a more necessary part of the philosophical character than a thoughtful regard for previous thinkers, and for the collective mind of the human race." ${ }^{\prime 61}$

No one makes his or her way in the world alone; Skinner's own historical method, for example, owes much to his mentors Hebert Butterfield and Peter Laslett. Butterfield and Laslett are now deceased. Yet if it was ethically permissible for Skinner and his peers to learn from them when they were still alive, surely it is still permissible for us. And if it is permissible for us to learn from Butterfield, perhaps we can also learn from Butterfield's inspiration R. G. Collingwood. And if it is permissible for us to learn from Collingwood, perhaps we can also learn from F. H. Bradley. And if we can learn from Bradley, perhaps we can also learn from Hegel. Back it goes until we reach Socrates and Plato, who have been inspirations to us all.

Of course, good teachers do not want slavish disciples. They want students who can think for themselves, but who do so in a way that would have been impossible if not for their teachers and mentors. Skinner did not simply copy Butterfield and Laslett, but built on them and extended their insights, just as good students have been doing since before Aristotle first diverged from the views of Plato. Good pupils of long-dead canonical authors do the same.

To be sure, if we can still be successful students of even Socrates and Plato, this implies that there is less of a chasm of difference between the present and the past than Skinner 
sometimes, at his most critical moments, seems to believe. Seeing similarities as well as differences between historical epochs, however, is not necessarily unrealistic, or even antihistorical. . ${ }^{62}$ As Christopher Janaway and Peter Alexander observe, the past does not display a uniform dissimilarity from the present, but ranges from "identity, through partial similarity, to

analogy, to incommensurability. ${ }^{.63}$ Where to situate a particular case on this spectrum cannot be determined a priori, but only by careful research about both of the eras under consideration.

There is always the possibility that we will err on the side of seeing too much difference instead of erring on the side of seeing too much similarity, as Skinner himself may have done when he failed to notice the return of mercenaries at the end of the twentieth century.

Sometimes, history serves its critical function by highlighting the continuity, rather than the discontinuity, of the values of the past with our own. For example, the large and vibrant literature on the relationship between liberalism and imperialism in the nineteenth century provides considerable resources for criticism of liberalism's imperialist tendencies today. At other times, however, the possibility of similarity between the past and the present allow history to serve important social functions that do not qualify as critical at all.

\section{The Argument for Monumental History and Presentist Theory}

It is difficult for even the most committedly critical historians to refuse to learn from, as well as about, the objects of their study. Skinner, in contrast to Elton, has long known that we must choose among the infinite array of possible objects of knowledge in the world based on criteria other than the intrinsic value of truth. "The decisions we have to make about what to study must be our decisions," he says, "arrived at by applying our own criteria for judging what is right and significant. ${ }^{, 64}$ It seems likely that any author from the past significant enough to still 
be worth studying today is likely to be in possession of some piece of practical wisdom worth reclaiming. In one interview, Skinner went so far as to say that "The reason for studying the past is that, as my great mentor in Princeton, Geertz, always used to say, 'These guys are meant to be working for us!" Historical scholarship, he explains, is meant to "illuminate our world, and if it doesn't we're not going to publish our results because they're not going to be important." ${ }^{\prime 65}$

Over the course of his career, Skinner has gradually moved from what Nietzsche calls critical to what he calls "monumental" history, to the positive celebration of past accomplishments as potential models for life today, an enterprise virtually indistinguishable from presentist theory. Many have noticed this turn in Skinner's thought ${ }^{66}$ although Skinner himself has never fully admitted to it. He may "no longer entirely endorse" all of what he wrote in the programmatic essays of the sixties and seventies, but Skinner insists that he still holds by most of it. ${ }^{67}$ Clearly, Skinner has never entirely abandoned his critical project. In recent decades, however, it has become obvious that he is now also engaged in a positive, monumental project, one of "bringing buried intellectual treasure back to the surface." ${ }^{" 68}$ Far from criticizing all traditions of political thought, Skinner now seems to defend at least one of them, one which he hopes might serve as "a shared European heritage," perhaps even as the basis of a new form of political order. ${ }^{69}$

As is well known, Skinner has become interested in the neo-Roman conception of republican liberty, one opposed to the now-dominant liberal conception. Yet if neo-Roman liberty is to serve a constructive rather than merely a critical function in contemporary politics, it cannot merely shock us with its intractable alienness. It must, in some modified form, remain a live option for us today. Rather than focusing on difference and discontinuity alone, Skinner must now give equal time to similarity and continuity. "If the study of intellectual history is to 
have the kind of use I am claiming for it," he acknowledges, "there must be some deeper level at which our present values and the seemingly alien assumptions of our forebears to some degree match up." ${ }^{, 70}$ It is certainly possible that ceasing his one-sided focus on difference has improved Skinner's work as a historian; his description of the past may now be more accurate. Yet by making this turn toward the constructive reclamation of lost ideals in order to improve our politics, Skinner has become, at least in part, a presentist political theorist. ${ }^{71}$

At least initially, Skinner was not entirely comfortable in his new role. In Liberty Before Liberalism, he still insists that the reclamation of republican liberty is not a normative project as such. In the classic voice of the Weberian social scientist, Skinner claims that the goal of even a seemingly monumental historian is only to "provide their readers with information relevant to the making of judgments about their current values and beliefs, and then leave them to ruminate." ${ }^{72}$ Such is the historian's limited vocation; philosophers (presumably neo-republican ones like Philip Pettit) must handle the rest.

Some have been attracted to this moral modesty; Kari Palonen praises this "indirect, historical style of theorizing" because it "does not patronize present political agents by suggesting how they should act." ${ }^{\text {73 }}$ Others have objected; Jens Bartelson observes that, for allegedly value-neutral historians, "the unwillingness to patronize becomes equally an unwillingness to take responsibility for one's normative judgments, however well concealed these might be. ${ }^{14}$

In Skinner's case, however, normative judgments are barely concealed at all. It hardly takes a strongly esotericist reading of Liberty Before Liberalism to determine whether the "before" or "after" picture is the one that Skinner prefers. If anyone is responsible for the neorepublican revival among normative political theorists, it is Skinner himself. And as this revival 
begins to have practical impact-think only of Pettit's involvement in Spanish politics ${ }^{75}$ — these real-world repercussions will, at least in part, be Skinner's responsibility as well.

In a more recent excavation of buried treasures from the history of political thought, Skinner's mask of value-neutrality drops almost entirely. In his "Genealogy of the Modern State," Skinner begins by insisting that his goal is to "free us to re-imagine the concept in different and perhaps more fruitful ways," suggesting that any prescriptive conclusions to be drawn from his work must be drawn from the reader's own ethical commitments. By the end of the genealogy, however, Skinner explicitly concludes that "the earlier and more explicitly normative ways of thinking about the state" that his scholarship brings to light represent " a way of thinking that ought never to have been set aside.",76

If nihilism is the great danger posed by too much critical history, action-guiding monumental history and presentist theory also have their dangers. Monumental history "deceives by analogies," Nietzsche writes, "with seductive similarities it inspires the courageous to foolhardiness and the inspired to fanaticism; and when we go on to think of this kind of history in the hands and heads of gifted egoists and visionary scoundrels, then we see empires destroyed, princes murdered, wars and revolutions launched." ${ }^{\prime 77}$

This does not sound much like the neo-republican revival that Skinner has inspired, Spain's ill fortune under Pettit's guidance notwithstanding. Yet it is not too far from what the most extreme critics of Leo Strauss believe has occurred in the name of a misguided political theory inspired by deceptively monumental history. The stakes are high when one is participating in a scholarly enterprise with direct practical implications.

Critical history is valuable when it helps prevent the worst sorts of misguidedly monumental presentist theorizing. Yet intellectual history can also play a positive role in helping 
produce good monumental presentist theory. Together, these are the best justifications that historians of political thought can make, not only for the value of their work, but also for their need to operate with at least some degree of autonomy. The value of basic research can never be predicted accurately; scholarship on mercenaries that was reasonably thought to be of purely historical interest may take on new political relevance when private military companies reemerge. "What we can learn from the past is always what we can succeed in learning," Dunn observes, "and the educative past can change_ as if some disused Mendip lead-working were one day to disclose a new and precious sort of uranium."78

If historians wish to leave it to political theorists to separate the uranium from the leadthat is, if they wish to remain value-neutral scholars who leave it to others to tease out the normative implications of their work - then there is no inherent ethical objection to this division of labor. Nor, however, would there be any ethical objection were historians to abandon their Weberian stance. It seems at least prima facie plausible that those who are best suited to determine the political application of once-buried treasures are sometimes those who first unearthed them. This is why Green is opposed to what he calls the excessive "ethic of specialization" separating intellectual history from political theory ${ }^{79}$

Although Dunn admits that "to understand what its author meant could never be sufficient for assessing the current significance of a great text's arguments," he nonetheless maintains that "it is both impertinent and ludicrous to assume that is not in general a wise preliminary in trying to do so." ${ }^{80}$ It is true that, for scholars practicing what Dunn recommends, history is in some sense prior to theory, in the sense that historical research must be performed before presentist application can begin. Yet if intellectual history must take temporal priority 
over presentist theory, theory takes ethical priority over history, since it ultimately the contemporary application that justifies the preliminary historical research, rather than vice versa.

In this spirit, Margaret Leslie describes intellectual history as a "storehouse of materials"- a "collection of ideas, images and possibilities" — that should be kept ready-at-hand for use in "conceptual bricolage." She lauds anachronistic bricoleurs as a creative class of "unquestionable value." ${ }^{81}$ While those who devote themselves exclusively to stocking the storehouse are also performing a needed service, their status is fundamentally that of intellectual under-laborers. One could encourage these laborers to engage in a bit of creative bricolage themselves, but if they refuse to do so, their work will be justified as long as others do it for them.

\section{Conclusion}

A central goal of this essay has been to show that one of the main allegedly methodological debates in the study of political thought is not primarily methodological. A method is a means to a given end, a piece of intellectual technology. Methodology is the art of choosing the proper technique for a given question, of picking the right tool for the job, and designing new tools when necessary. An academic focus on methodology has a strong affinity with a larger culture of instrumental rationality, one in which the dominant framework for understanding human activity is in terms of the rational selection of the most efficient means to a given end.

Just as instrumental rationality is silent about what ends we should choose, so too is methodology, or at least it ought to be. In recent years, methodology has often trespassed beyond its proper boundaries. The result is the sort of method-driven work criticized by Ian Shapiro, 
work in which the problems researchers address are determined by the methods that they wish to use, in which everything looks like a nail because we have nothing but hammers. ${ }^{82}$ At its worst, method-driven research can be rejected in purely methodological terms: the wrong tools have been picked for a given job because they were the tools that the researcher had at hand. Yet smarter method-driven research can avoid this criticism by carefully selecting a task for which the researcher's preferred hammer genuinely is the best available tool. To this, Shapiro replies that worthwhile, problem-driven research must answer a question of real importance. Identifying such questions, however, requires a convincing account of what makes an issue important and why.

Those who rely only on instrumental rationality to explain human action tend to think that our ends are set by our idiosyncratic preferences, tastes, or whims. While our methodscentered discourse does not leave academics bereft of any intellectual resources for justifying why we address the questions that we do, the richness of our discourse about means has left our discourse about ends relatively impoverished. When our research addresses what others consider to be a pointless question, the most common objection is that it is trivial or uninteresting. One could reasonably worry that this is just another way of talking about arbitrary tastes and preferences. Often, however, this is actually an under-theorized way of talking about what are best understood as important ethical disagreements.

I hope that even adamant anti-presentists who reject the specific ethical arguments made in this essay will nonetheless be convinced that the dispute between intellectual history and presentist political theory is indeed an ethical one. There is reason to suspect that this thesis is generalizable to other, similar disputes across the academy. I have already made the argument that this is the case with regard to the present dispute between ideal and nonideal methods of 
normative political theory, which is better understood as a disagreement about professional ethics than about methodology per se. ${ }^{83}$ My suspicion is that this also holds true for a wide variety of other alleged Methodenstreiten, such as the quarrel between quantitative and qualitative social scientists and that between value-neutral researchers and scholar-activists. Confirming this hypothesis, as well as evaluating the relevant ethical arguments available, is the subject of my current research.

${ }^{1}$ Susan Wolf, Meaning in Life and Why it Matters. (Princeton, NJ: Princeton University Press, 2012), 43. Wolf herself insists that both the locus and judgment of value must be objective, but discourse ethics allows for the substitution of intersubjective justifiability for objectivity.

${ }^{2}$ John Rawls, A Theory of Justice (Cambridge, MA: Harvard University Press, 1971), p. 441.

${ }^{3}$ See Jeffrey Moriarty, "Rawls, Self-Respect and the Opportunity for Meaningful Work," Social Theory and Practice 35:3 (2009): 441-459.

${ }^{4}$ For a book-long defense of this claim, see Andrea Veltman, Meaningful Work. (New York: Oxford University Press, 2016).

${ }^{5}$ Jeffrey Edward Green, "On the Difference Between a Pupil and a Historian of Ideas.” Journal of the Philosophy of History 6 (2012): 84-110. 
${ }^{6}$ Deborah Baumgold, "Political Commentary on the History of Political Theory." American Political Science Review 75 (1981): 928-940

${ }^{7}$ See Green, "Political Theory as Both Philosophy and History: A Defense Against Methodological Militancy." The Annual Review of Political Science 18 (2015): 425-441.

${ }^{8}$ David Easton, “The Decline of Modern Political Theory.” The Journal of Politics 13 (1951): 36-58, 42. See also J. A. W. Gunn, “After Sabine, After Lovejoy: The Languages of Political Thought." Journal of History and Politics 6 (1988): 1-45, 5.

${ }^{9}$ Quentin Skinner, Visions of Politics: Volume I: Regarding Method. (New York: Cambridge University Press 2002), vii.

${ }^{10}$ Bruce Haddock, "Contingency and Judgment in History of Political Philosophy: A Phenomenological Approach.” Political Philosophy versus History? Contextualism and Real Politics in Contemporary Political Thought, ed. Jonathan Floyd and Marc Stears. (New York: Cambridge University Press, 2011): 65-83, 66.

${ }^{11}$ Skinner, Visions of Politics I, 89.

${ }^{12}$ When interpreting these authors, my own approach will be presentist rather than historical. While this could be criticized as viciously circular or lauded as admirably consistent, I take it 
mostly as proof that the sort of ethical choices I am describing are unavoidable, even in an essay about these very choices.

${ }^{13}$ Skinner, "Meaning and Understanding in the History of Ideas." History and Theory 8 (1969): $3-53,48$.

${ }^{14}$ Hans-Georg Gadamer, Truth and Method, Revised Edition, ed. Joel Winsheimer and Donald G. Marshall. (New York: Continuum Publishing, 1989), 296. For a rejection of Skinner's approach as impossible for Gadamerian reasons, see John Keane, “On the 'New’ History: Quentin Skinner's Proposal for a New History of Political Ideology.” Telos 47 (1981): 174-183. For more on the incompatibility of Gademerian and Skinnerian approaches, see David Boucher, Texts in Contexts: Revisionist Methods for Studying the History of Ideas (Boston: Martinus Nijhoff 1985), especially 181. Skinner has sometimes attempted to incorporate Gadamer's ideas into his own hermeneutic theory, although it is not clear if this can be successful; see Skinner, Visions of Politics I, 15-16.

${ }^{15}$ See, among many others, Mark Bevir, Are there Any Perennial Problems in Political Theory?" Political Studies 42 (1994): 662-675; Robert Lamb, “Quentin Skinner's Revised Historical Contextualism: A Critique." History of the Human Sciences 22 (2009): 51-73; and Paul Kelly, "Rescuing Political Theory from the Tyranny of History." In Floyd and Stears, eds., op cit.: 1337. 


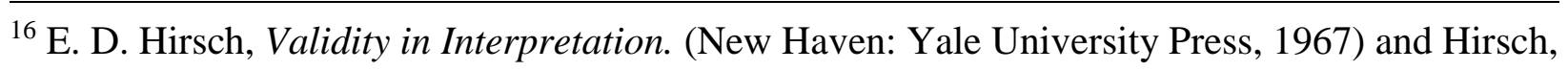
The Aims of Interpretation, (Chicago: The University of Chicago Press 1976). Hirsch's terminology is unfortunately misleading, since his concept of "significance" seems like a better candidate for what is colloquially meant by "meaning" (i.e., "what this means to us") than what he calls "meaning." For a subtler analysis of the multiple meanings of "meaning," see Aloysius Martinich, 'Four Senses of 'Meaning' in the History of Ideas: Quentin Skinner's Theory of Historical Interpretation." Journal of the Philosophy of History 3 (2009): 225-245. Furthermore, if Paul Ricoeur is correct that every text contains a surplus of meaning, then there are far more ways of understanding a text than just the two described by Hirsch; see Ricouer, Hermeneutics and the Human Sciences. Edited and Translated by John B. Thompson. (New York: Cambridge University Press, 1981).

${ }^{17}$ Skinner, Visions of Politics I, 87.

${ }^{18}$ Skinner, "A Reply to My Critics.” In Meaning and Context: Quentin Skinner and His Critics, ed. James Tully. (Princeton: Princeton University Press, 1988): 231-288, 256.

${ }^{19}$ Skinner, Visions of Politics I, 52-53.

${ }^{20}$ See Sean McFate, The Modern Mercenary: Private Armies and What They Mean for World Order. (New York: Oxford University Press, 2015). 
${ }^{21}$ Ronald Dworkin, Justice for Hedgehogs. (Cambridge, MA: Harvard University Press, 2011), 99-190.

${ }^{22}$ Hirsch, The Aims of Interpretation, 7.

${ }^{23}$ Friedrich Nietzsche, “On the Uses and Disadvantages of History for Life.” In Untimely Meditations, Translated and Edited by R. J. Hollingdale. (New York: Cambridge University Press, 1983).

${ }^{24}$ Hirsch, The Aims of Interpretation, 90.

${ }^{25}$ Skinner, Visions of Politics I, 65.

26 Ibid.

${ }^{27}$ Many of the most important contributions to this literature are collected in John Martin Fischer, ed. The Metaphysics of Death. Stanford Series in Philosophy. (Stanford, CA: Stanford University Press, 1993). For an application of these ideas to research ethics specifically, see T. M. Wilkinson, "Last Rights: The Ethics of Research on the Dead." Journal of Applied Philosophy 19 (2002): 31-41.

${ }^{28}$ Raymond Angelo Belliotti, Posthumous Harm: Why the Dead are Still Vulnerable (Lanham, MD: Lexington Books, 2012), 34. 
${ }^{29}$ See Ernest Partridge, "Posthumous Interests and Posthumous Respect.” Ethics 91 (1981): 243264 and James Stacey Taylor, Death, Poshumous Harm, and Bioethics (New York: Routledge, 2012), 67.

30 Thucydides, History of the Peloponnesian War. Translated by Rex Warner (New York: Penguin Books, 1972), 48.

${ }^{31}$ On the former point, see Kelly, "Rescuing Political Theory,” 26 and Lamb, “Quentin Skinner's Revised Historical Contextualism," 57-58. On the latter, see Green, “On the Difference Between a Pupil and a Historian of Ideas," 107-108.

${ }^{32}$ Skinner, "Conventions and the Understanding of Speech Acts." The Philosophical Quarterly 20 (1970): 118-138, 134.

${ }^{33}$ Dorothy Grover, "Posthumous Harm.” The Philosophical Quarterly 39 (1989): 334-353, 353.

${ }^{34}$ Niccoló Machiavelli, The Prince. Translated with an Introduction by Harvey Mansfield. Second Edition. (Chicago: University of Chicago Press, 1988), 61.

${ }^{35}$ In Ibid., 107-111.

${ }^{36}$ Skinner, Visions of Politics I, 53 
${ }^{37}$ Max Weber, "Science as a Vocation.” In From Max Weber: Essays in Sociology, Edited and Translated by H. Gerth and C. Wright Mills (New York: Oxford University Press, 1946).

38 John Dunn, “The Identity of the History of Ideas.” Philosophy 43 (1968): 85-104, 89.

${ }^{39}$ Skinner, Visions of Politics I, 182.

${ }^{40}$ Ibid., 170-171.

${ }^{41}$ That said, there are many within the discipline of history who have made precisely this attempt For an influential defense of "dialogical history" along these lines, see Dominick LaCapra, Rethinking Intellectual History: Texts, Contexts, Language (Ithaca, NY: Cornell University Press 1983). It is important to note that many who self-identify as historians, or are employed as such, would nonetheless qualify as presentists according to the schema of ideal types used in this essay.

${ }^{42}$ Citation omitted for purposes of blind review.

${ }^{43}$ Arthur Applebaum, Ethics for Adversaries: The Morality of Roles in Public and Professional Life (Princeton, NJ: Princeton University Press, 2000).

${ }^{44}$ Herbert Butterfield, The Whig Interpretation of History (New York: W. W. Norton, 1965), 16. 
${ }^{45}$ G. E. Moore, Principia Ethica (Cambridge: Cambridge University Press 1903), viii.

${ }^{46}$ Robert Audi, The Good in the Right: A Theory of Intuition and Intrinsic Value. (Princeton, NJ: Princeton University Press 2004), 149.

${ }^{47}$ John Henry Newman, Discourses on the Scope and Nature of University Education (Dublin: James Duffy, 1852).

${ }^{48}$ G. R. Elton, The Practice of History. (London: Fontana Press, 1969).

${ }^{49}$ See Scott A. Davison, On the Intrinsic Value of Everything. (New York: Continuum, 2012).

${ }^{50}$ Skinner, Visions of Politics I, 15-21.

${ }^{51}$ Beverly Southgate, What is History For? (New York: Routledge 2005), 76.

${ }^{52}$ See T.K. Seung and Daniel Bonevac, "Plural Values and Indeterminate Rankings.” Ethics 102 (1992):799-813.

${ }^{53}$ Cicero, On Duties, Translated and Edited by M. T. Griffin and E. M. Atkins. (New York: Cambridge University Press, 1991), 60. 
${ }^{54}$ See Michael L. Frazer, "Utopophobia as a Vocation: The Professional Ethics of Ideal and Nonideal Political Theory." Social Philosophy and Policy 33 (2016): 175-192, which begins with the same passage from Cicero discussed here.

55 This is not to say that all—or even most—political theory succeeds in advancing the cause of justice. The majority of it probably has no effect on real politics at all, while some of it (as will be discussed later) may actually prove deleterious. That said, activities often fail to achieve their goals, and we can separate our judgment of the value of an aim from the success of any given effort to attain it.

${ }^{56}$ Skinner, Visions of Politics I, 6.

${ }^{57}$ Nietzsche, Untimely Meditations, 75-77. It is important to note that, contrary to popular belief, Skinner has never actually been an antiquarian, at least not in Nietzsche's sense. Antiquarians, Nietzsche says, piously preserve, and hence kill and mummify, the treasures of the past. See Ibid., 72-75.

${ }^{58}$ Skinner, Visions of Politics I, 88.

${ }^{59}$ Nietzsche, Untimely Meditations, 76.

${ }^{60}$ Skinner, Visions of Politics, 88. 
${ }^{61}$ John Stuart Mill, “Bentham,” In Utilitarianism and On Liberty: Including Essay on Bentham and Selections from the Writings of Jeremy Bentham and John Austin, Edited by Mary Warnock. (Malden, MA: Blackwell Publishers, 2003), 64.

${ }^{62}$ Karl Popper maintained that one of the many flaws of what he called "historicism" (most of which, admittedly, bear little or no resemblance to anything Skinner would ever defend) was its tendency to exaggerate "the somewhat spectacular differences between various historical periods.” See Karl Popper, The Poverty of Historicism. (New York: Routledge, 1997), 100.

${ }^{63}$ Christopher Janaway and Peter Alexander, "History of Philosophy: The Analytical Ideal." Proceedings of the Aristotelian Society: Supplementary Volumes 62 (1988): 169-208, 182. Melissa Lane agrees, writing that "the history of some ideas will teach contingency, while the history of other ideas will teach continuity, and if that were not so then the piecemeal emergence of the present from the past could not have been possible, as it was"; Lane, "Why History of Ideas at All?" History of European Ideas 28 (2002): 33-41, 39. See also Lane, “Constraint, Freedom and Exemplar: History and Theory without Teleology.” In Floyd and Stears, eds., op. cit., 128-150; Stephanie Lawson, "Political Studies and the Contextual Turn: A Methodological/Normative Critique." Political Studies 56 (2008): 584-603, 592; and the introduction and titular essay in Preston King, Thinking Past a Problem: Essays on the History of Ideas (Portland, OR: Frank Cass Publishers, 2000).

${ }^{64}$ Skinner, "Some Problems in the Analysis of Political Thought and Action." Political Theory 23 (1974): 277-303, 281. 
65 “Quentin Skinner on Meaning and Method.” Interview by Teresa Bejan. The Art of Theory, 2011. Online at http://www.artoftheory.com/quentin-skinner-on-meaning-and-method/.

${ }^{66}$ See, for example, Lamb, "Recent Developments in the Thought of Quentin Skinner and the Ambitions of Contextualism." Journal of the Philosophy of History 3(2009): 246-265, and Lane, “Doing Our Own Thinking for Ourselves: On Quentin Skinner's Genealogical Turn.” Journal of the History of Ideas 73 (2012): 71-82.

${ }^{67}$ Skinner, Visions of Politics I, vi.

${ }^{68}$ Skinner, Liberty Before Liberalism. (New York: Cambridge University Press, 1998), 112.

${ }^{69}$ Martin Van Gelderen and Quentin Skinner, editors, Republicanism: A Shared European Heritage (New York: Cambridge University Press, 2002).

${ }^{70}$ Skinner, "Some Problems in the Analysis of Political Thought and Action," in Tully, ed., 1988, op. cit.: 97-119, 117.

${ }^{71}$ See Max Edling, and Uld Mörkenstam, “Quentin Skinner: From Historian to Political Scientist." Scandinavian Political Studies 18 (1995): 119-132.

${ }^{72}$ Skinner, Liberty Before Liberalism, 118. 
${ }^{73}$ Kari Palonen, “The History of Concepts as a Style of Political Theorizing: Quentin Skinner's and Reinhart Koselleck's Subversion of Normative Political Theory." European Journal of Political Theory 1 (2002): 91-106.

74 Jens Bartelson, "Philosophy and History in the Study of Political Thought." Journal of the Philosophy of History 1 (2007): 101-124, 111-112.

${ }^{75}$ See Philip Pettit, and Jose Luis Marti, A Political Philosophy in Public Life: Civic Republicanism in Zapatero's Spain. (Princeton, NJ: Princeton University Press, 2010).

${ }^{76}$ Skinner, “A Genealogy of the Modern State.” Proceedings of the British Academy 162 (2009): 325-370. I owe the observation of the explicit prescriptivism of this conclusion, and its tension with what Skinner says in the introduction to the piece, to Lane "Doing Our Own Thinking for Ourselves," 81-82.

${ }^{77}$ Nietzsche, Untimely Meditations, 71.

${ }^{78}$ Dunn, "The Identity of the History of Ideas," 98.

${ }^{79}$ Green, “On the Difference Between a Pupil and a Historian of Ideas.” For a similar argument against a rigid division of intellectual labor, see Margaret Leslie, "In Defense of Anachronism." Political Studies 18 (1970): 433-447, 441-447. 
${ }^{80}$ Dunn, The History of Political Theory and Other Essays (New York: Cambridge University Press 1996), 26.

${ }^{81}$ Leslie, "In Defense of Anachronism," 443.

${ }^{82}$ Ian Shapiro, The Flight from Reality in the Human Sciences (Princeton, NJ: Princeton University Press, 2005).

${ }^{83}$ This is the thesis of Frazer, "Utopophobia as a Vocation," where I argue that political theorists have a professional responsibility to offer a valuable service to their fellow citizens and must not get lost in the construction of useless utopias. 